\title{
The pesticide chlordecone is trapped in the tortuous mesoporosity of allophane clays
}

\author{
Thierry Woignier ${ }^{1,2}$ - Florence Clostre ${ }^{3}$ Paula Fernandes ${ }^{3,4}$ - Alain Soler ${ }^{5}$. \\ Luc Rangon ${ }^{1,2}$ • Maria Isabel Sastre-Conde ${ }^{6}$ - Magalie Lesueur Jannoyer ${ }^{3,4}$
}

\begin{abstract}
Some volcanic soils like andosols contain shortrange order nanoclays (allophane) which build aggregates with a tortuous and fractal microstructure. The aim of the work was to study the influence of the microstructure and mesoporosity of the allophane aggregates on the pesticide chlordecone retention in soils. Our study shows that the allophane microstructure favors pollutants accumulation and sequestration in soils. We put forth the importance of the mesoporous microstructure of the allophane aggregates for pollutant trapping in andosols. We show that the soil contamination increases with the allophane content but also with the mesopore volume, the tortuosity, and the size of the fractal aggregate. Moreover, the pore structure of the allophane aggregates at nanoscale favors the pesticide retention. The fractal
\end{abstract}

Thierry Woignier

thierry.woignier@imbe.fr

1 Institut Méditerranéen de Biodiversité et d'Ecologie marine et continentale (IMBE), Aix Marseille Université, CNRS, IRD, Avignon Université, 13397 Marseille Cedex 20, France

2 IRD, UMR IMBE, Campus Agro Environnemental Caraibes B. P. 214 Petit Morne, 97235 Le Lamentin, Martinique

3 Cirad, UPR fonctionnement agroécologique et performances des systèmes de culture horticoles, Campus Agro Environnemental Caraïbes B.P. 214 Petit Morne, 97232 Le Lamentin, Martinique

4 Cirad UR HortSys, TA B-103/PS4, Boulevard de la Lironde, 34398 Montpellier Cedex5, France

5 Cirad UR Banana, plantain and pinneapple cropping system, Campus Agro Environnemental Caraibes B.P. 214 Petit Morne, 97232 Le Lamentin, Martinique

6 SEMILLA-INAGEA, C/ Babieca, $\mathrm{n}^{\circ}$ 2. Son Ferriol, Palma de Mallorca Balearic Island, Spain and tortuous aggregates of nanoparticles play the role of nanolabyrinths. It is suggested that chlordecone storage in allophanic soils could be the result of the low transport properties (permeability and diffusion) in the allophane aggregates. The poor accessibility to the pesticide trapped in the mesopore of allophane aggregates could explain the lower pollutant release in the environment.

Keywords Chlordecone - Soil contamination - Allophane · Mesoporosity $\cdot$ Tortuosity $\cdot$ Fractal microstructure

\section{Introduction}

Andosols contain clay (allophane) that presents unique structures and physical properties compared to crystalline clays. Allophane is a short-range order aluminosilicate, the unit cell of which appears as spheroids with a diameter between 3 and $5 \mathrm{~nm}$ (Wada 1985) forming aggregates with a fractal structure (Adachi and Karube 1999; Chevallier et al. 2008; Wada 1985; Woignier et al. 2008). The original properties of allophane have been used in various fields for trapping purpose. Recently allophane has been found to be effective in the stabilization of $\mathrm{C}$ in soil and composts, offering perspectives for carbon sequestration technology (Bolan et al. 2012; CalabiFloody et al. 2011). Synthetic allophane has also been studied as adsorbents for organic pollutants (Espinoza et al. 2009).

Chlordecone (CLD) is an organochlorine pesticide. It is a highly hydrophobic organochlorine pesticide $\left(K_{\text {ow }}\right.$ between 4.9 and 5.4) and poorly soluble $\left(0.35-3 \mathrm{mg} \mathrm{L}^{-1}\right.$ ) (Soler et al. 2014; U.S. Environmental Protection Agency 2012). It is generally admitted that chlordecone is poorly biodegradable especially in environmental conditions explaining its persistence in soils (Cabidoche et al. 2009; Epstein 1978; UNEP 2007). The CLD poor biodegradability is attributed to its peculiar 
chemical structure (bishomocubane "cage") and the high steric hindrance caused by the ten chlorine atoms. However, Dolfing et al. (2012) showed that there were no thermodynamic reasons why chlordecone-respiring or chlordeconefermenting organisms should not exist. Previous work studied variations in the ratio of CLD-5b-hydro to CLD in soils (Clostre et al. 2015a). The mean ratio was lower in andosols than in nitisols. The differences in ratios between andosols and nitisols could be due to a lower biodegradation of CLD to CLD-5b-hydro, because of a lower availability in andosols. Chlordecone biodegradation is not impossible but at least very restricted in these clays.

This neurotoxic and carcinogenic molecule (Dallaire et al. 2012; Epstein 1978) still persists in the soil for centuries and contaminates foodstuffs and water resources (Coat et al. 2011; Fung et al. 2005; Clostre et al. 2015b; Jondreville et al. 2014; Della Rossa et al. 2017) thus leading to human exposure through food (Dubuisson et al. 2007; Gimou et al. 2008). The bioaccumulation process leads to the contamination of the entire food web. Recently, a book provides a presentation of various aspects of chlordecone pollution (Lesueur et al. 2016).

Water is the main vehicle of pesticides transport; so, water flow is an important point to consider. However, few studies have focused on pesticide transfers in andosols. When comparing cadusafos leaching in andosols and nitisols, it appeared that cumulated water pollution by cadusafos stemming from nitisol percolation was much greater than that from andosols (Cabidoche et al. 2009). In the case of CLD, Cabidoche et al. (2009) collected samples from lysimeters installed on an andosol and a nitisol. They observed that the concentrations of CLD in similar volumes of drainage water were 3 to 4-fold higher in the nitisol than in the andosol. This finding suggested that the desorption capacity of nitisol was higher than that of andosol.

These results are consistent with results on soil to crops contamination found in the literature. Contamination of crops by soil CLD depended on the type of soil: andosols were less contaminating than nitisols (Cabidoche and Lesueur-Jannoyer 2012; Woignier et al. 2015). Studies on chlordecone transfer to water and crops led to the general assessment that andosol tends to retain the pesticide more than other soils.

So, the literature shows that andosols are generally more polluted by CLD than the other kinds of tropical soils (nitisols, ferralsols) but they release less pesticide to the environment (Cabidoche et al. 2009; Cabidoche and Lesueur-Jannoyer 2012; Woignier et al. 2012). Organic matter and mineral surface (Pignatello 1998; Vlčková and Hofman 2012) are well known to influence pesticide retention in soils but physical properties of soil porous structure are seldom studied.

In its natural state, the clay consists of aggregations of spherical allophane particles (Wada 1985; Wells and Theng 1985; Lindner et al. 1998). Transmission electron microscopy shows allophane nano-spheres with a diameter of about $5 \mathrm{~nm}$ (Wada 1985; Calabi-Floody et al. 2011; Chevallier et al. 2008). The allophane spherule aggregates (average diameter $100 \mathrm{~nm}$ ) and organo-mineral complexes form small aggregates with pores in the mesopore scale $(2-50 \mathrm{~nm})$ and with high organic matter loadings. Seventy-five to $90 \%$ of the soil organic matter found in the pores is in the $10-1000 \mathrm{~nm}$ size range (McCarthy et al. 2008).

The present study hypothesizes that the peculiar properties of allophane and specially the porous and tortuous microstructure of allophane aggregates favor pollutant accumulation in soils and hinder the transfer to the environment. We thus focus on the physical properties of the allophane clay to explain the pollutant trapping.

For that, we propose to do the following:

1) Measure the water chlordecone contamination from andosols having different allophane content.

2) Show the influence of allophane concentration on porous features of soils. We measure the porous properties (specific surface area, pore volume, fractal features) of several andosols by small angles X-ray scattering and nitrogen adsorption techniques.

3) Finally, we put forth the importance of the clay microstructure (fractal range, mesoporous volume, and tortuosity) for pollutant trapping.

\section{Experimental}

\section{Soil samples}

We sampled 31 soils, andosols (allophane clay) and nitisols (halloysite clay), in Martinique $\left(14^{\circ} 40 \mathrm{~N}, 61^{\circ} 00 \mathrm{~W}\right)$ in the vicinity of the "Montagne Pelée" volcano. These two kinds of soils are representative of the main polluted soils found in French West Indies (Brunet et al. 2009; Cabidoche et al. 2009). The soils we selected were known to be historically polluted by CLD. The soils samples were retained in closed containers to avoid moisture evaporation and associated structural changes of allophanes. Samples were stored during 7 days at $4{ }^{\circ} \mathrm{C}$.

The allophanic content was measured by the method of Mizota and van Reewijk (1989) using Al and Si content extracted by oxalate and pyrophosphate and measured by inductively coupled plasma atomic emission spectroscopy (ICPAES ICAP 6500, Thermo Scientific, France). The soils samples covered the allophane range 0 to $26 \%$ ( $w / w$ basis).

The crystalline and amorphous structure was studied by Xray diffraction $(\mathrm{Cu} K \alpha)$ with a Philips PW 1830. Before X-ray diffraction, the samples are dried at $90{ }^{\circ} \mathrm{C}$ and the powder is ground at $40 \mu \mathrm{m}$. 
The presence of allophane was characterized by infrared spectroscopy. The apparatus used was an IR-FT Nicolet $510 \mathrm{P}$ spectrometer and the samples were diluted in $\mathrm{KBr}$ pellets with a $510^{-3}$ mass ratio.

Physical fractionation of soil organic matter by sieving in water (Bruckert et al. 1978; Feller 1979) as previously described (Clostre et al. 2014b). It was carried out after leaving $20 \mathrm{~g}$ of soil to stand overnight at $4{ }^{\circ} \mathrm{C}$ in $300 \mathrm{~cm}^{3}$ of water added with $0.5 \mathrm{~g}$ of hexametaphosphate, followed by shaking for $6 \mathrm{~h}$ at $50 \mathrm{rpm}$ with five glass balls $1 \mathrm{~cm}$ in diameter. This method separates the different organo-mineral soil fractions according to their particle size. In our case, we separated three fractions: (1) $0-50 \mu \mathrm{m}$, corresponding to the soil organic matter associated with clay and silt (fine fraction), this fraction contained stable allophane microaggregates; (2) 50-200 $\mu \mathrm{m}$, corresponding to pre-humified or partially mineralized organic debris of plant or animal origin and fecal pellets; and (3) 200-2000 $\mu \mathrm{m}$, corresponding to coarse sand and plant residues.

Three replicates of each fraction were prepared and CLD and organic carbon contents were analyzed in each replicate.

The carbon contents are measured with a $\mathrm{CHN}$ (Thermofinnigan) chromatograph analyzer.

\section{Transfer experiments}

The leaching experiment was performed through water extraction such as evaluating soil solution contamination by CLD. Micro-columns containing $5 \mathrm{~g}$ of soil were prepared with at least four replicates for each soil. Leaching with $12.5 \mathrm{~mL}$ of nanopure water was slightly forced by gentle centrifugation $(500 \times g)$ directly in the micro-columns. Nanopure water was used to avoid CLD contamination by tap water as described in Clostre et al. (2014b). Pure water was produced using a water purification system (Barnstead Nanopure Diamond) and an activated carbon filter (Bioblock Scientific ORC-83005). One important parameter in the leaching experiments is the $S / V$ ratio, where $S$ is the contact area and $V$ the liquid volume. In this study, the $S / V$ ratio was around $200 \mathrm{~cm}^{-1}$, which is comparable to the leaching test used for porous materials and nuclear waste glasses (Rebiscoul 2004; Woignier et al. 1998). The system was designed to preserve the soil structure as much as possible. After water passed through the soil columns, water CLD concentrations were determined by solidphase microextraction and gas chromatography mass spectrometry (GC450/MS240, Varian, Palo Alto, CA, USA) according to the procedure detailed in Soler et al. (2014). The soil to water transfer coefficient (WTC) is the ratio of the pesticide concentration in lixiviates to the pesticide concentration in soil expressed in microgram per liter/milligram per kilogram of dry soil.
CLD concentration in soils samples was analyzed by the LDA26 (Valence, France) as described in Cabidoche and Lesueur-Jannoyer (2012).

\section{Soils porous properties}

Porous and structural measurements generally require dried solid samples. A preliminary study (Woignier et al. 2005) has shown that the $\mathrm{CO}_{2}$ supercritical drying is necessary to preserve the porosity and microstructure of andosols. A critical point dryer (CPD 010, Balzers, Liechtenstein) was used in a procedure such as previously described (Woignier et al. 2005).

The specific surface area (SSA) of the sample was calculated from the adsorption curve at $\mathrm{P} / \mathrm{P} 0=0.3$ and the $\mathrm{BET}$ equation (Brunauer et al. 1938) by $\mathrm{N}_{2}$ adsorption-desorption curves (Micromeritics ASAP 20120, France). The soil powder was placed in a test tube to degas for $24 \mathrm{~h}$ at $50^{\circ} \mathrm{C}$ in a vacuum of $2-4 \mu \mathrm{m} \mathrm{Hg}$.

The pore volume was calculated from the bulk density and the solid density measured by He pycnometry for the different kinds of soils. The solid density is closed to $2.5 \mathrm{~g} . \mathrm{cm}^{-3}$ for the allophanic soils and 2.66 g.cm $\mathrm{cm}^{-3}$ for the halloysite soils (Dorel et al. 2000).

\section{Physical features of clay aggregates}

The morphology of allophane and halloysite clays was characterized by electron microscopy. The transmission electron micrographs were obtained with a Transmission Electron Microscope JEOL Type 1200 EX (100 kV). The scanning electron micrographs were obtained with a Cambridge stereo scan 360 scanning electron microscope.

The fractal features of the allophane aggregates were characterized by small angle X-ray scattering experiments (SAXS) in transmission mode. A copper rotating anode X-ray source (operating at $4 \mathrm{~kW}$ ), with a multilayer focusing "Osmic" monochromator giving high flux $\left(10^{8}\right.$ photons. $\left.^{-1}\right)$ and punctual collimation, was employed. The data from the SAXS experiments provided three types of information on the fractal geometry: the maximum size of the fractal clusters $(L)$, the size of the primary particles $(a)$ which built the clusters, and the fractal dimension $(D f)$ which characterized the spatial arrangement in the cluster (Marlière et al. 2001; Teixeira 1988). These experiments which characterize the clay microstructure between 1 to $100 \mathrm{~nm}$ cover the range of the allophane mesoporosity.

Mesopore volumes (the pore volume of clay aggregates) were determined as cumulative values in the range between 2 and $50 \mathrm{~nm}$ (Rouquerol et al. 1994) with a Barrett-JoynerHalenda method (BJH) (Barrett et al. 1951) using desorption branches of the $\mathrm{N}_{2}$ adsorption-desorption isotherms. 
Tortuosity $(t)$ inside the allophane aggregates is calculated from the fractal features; $t$ is a power law function of the length scale: $t \propto l^{\lambda-1}$ (Jullien and Botet 1987; Stanley et al. 1985). $\lambda$ is the tortuosity exponent and can be derived from the fractal dimension $(D f)$ and the spreading dimension $(D l) \lambda=D f / D l$. (Jullien and Botet 1987).

Thus, $t=L^{(D f / D l)-1} \cdot a^{(D f / D l)-1}$.

\section{Statistical analysis}

All statistical analyses were performed using XL STAT 2012.6.08 (Addinsoft 1995-2013). ANOVA and Tukey Honestly Significant Difference tests $(P<0.05)$ were used to compare means of transfer (WTC) for the different soil types and to assess the difference of CLD content in the different soil fractions for each soil type. The linear regressions and ANOVA were used to assess the equation of the linear models, their goodness of fit, and the significance of the explanatory variable.

\section{Results and discussion}

\section{Allophanic soils}

To confirm the presence of allophanes in the studied andosols, we used X-ray diffraction and infrared techniques.

X-ray patterns of studied andosols showed bulges of the baseline between 2 and $7 \AA$, according to the literature (Barois et al. 1998; Woignier et al. 2005), these bulges can be attributed to non-crystalline solids, allophane, and/or imogolite. While the X-ray diffraction patterns for nitisols showed peaks at 4.45 and $7.4 \AA$ that can be attributed to the clay halloysite (Dubroeucq et al. 1998; Onodera et al. 2001). The infrared spectroscopy confirmed the presence of allophane (characteristic bands like 506, 577 and a shoulder at $970 \mathrm{~cm}^{-1}$ ). Moreover, the IR spectra of the different studied andosols do not present doublets of the band at 577 and $967 \mathrm{~cm}^{-1}$ characteristic of the imogolite structure (Denaix et al. 1999; Gustafsson et al. 1995; Levard et al. 2012).

Andosols are derived from volcanic materials (ColmetDaage et al. 1965; Dubroeucq et al. 1998). These volcanic soils comprise weathering products such as allophane originating from the lixiviation of volcanic ash and glasses (Barois et al. 1998; Basile-Doelsch et al. 2005; Quantin et al. 1991). The literature shows that the clay consists of aggregations of spherical allophane particles (Wada 1985; Wells and Theng 1985; Lindner et al. 1998). Allophane spherules tend to form porous nanosized aggregates (Calabi-Floody et al. 2011; Garrido-Ramirez et al. 2012), whose average diameter is around $100 \mathrm{~nm}$ and there is a clear analogy between allophane aggregates and synthetic silica gels (Adachi and Karube 1999; Clark and McBride 1984; Chevallier et al. 2008).
We compare the structure of halloysite clay with that of allophane clay isolated from the studied nitisols and andosols (Fig. 1). The plate-like particles of phyllosilicate clay like halloysite are 300-1000 $\mathrm{nm}$ in size (Fig. 1a). In comparison, the scanning electron micrograph confirms the spongy structure of allophane clay with aggregates around $100 \mathrm{~nm}$ (Fig. 1b). The allophane aggregates are highly porous in the range of the mesoporosity (Calabi-Floody et al. 2011; Maeda et al. 2009).

From the transmission electron microscopy (Fig. 1c), we see that the morphology of the allophane aggregates is peculiar. Allophane has a very open structure made up of aggregated small particles that form clusters of around 10-20 nm. The clusters can stick together and form larger and larger aggregates up to $L \sim 100-300 \mathrm{~nm}$ in size (Fig. 1c). This hierarchical aggregation is characteristic of a fractal microstructure. The fractal features of the studied samples will be measured in "Influence of allophane content on soil pore properties" section.

\section{Transfer experiments}

The literature suggested that the desorption capacity of nitisol was higher than that of andosol (Cabidoche et al. 2009). Through the leaching experiment, we evaluated the contamination of the soil solution by chlordecone. The transfer of chlordecone to water (WTC, Table 1) was twice lower in allophane clay (andosol) than halloysite clay (nitisol) despite similar organic carbon content. The WTC were significantly different for the two soils $(P<0.0001)$.

It is generally admitted that the pesticide retention is soils is related to the organic matter content (Pignatello 1998) and to the sorption capacity of the mineral surface (Vlčková and Hofman 2012; Fushiwaki and Urano 2001). It has already been shown that organic carbon content could not account for CLD intra-field variability (Clostre et al. 2014a) and could only partially explain the lower uptake observed for plants growing in andosol compared to ferralsol and nitisol (Clostre et al. 2015b).

In this study, we showed that the higher the allophane content, the lower the WTC (Fig. 2, WTC $=-0.2548$ allophane $(\%)+4.5096, P<0.0001$ and $\left.r^{2}=0.7378\right)$ despite similar organic carbon content. In Fig. 2, the carbon content is $2.1 \mathrm{wt} \%$ for the nitisols ( $0 \%$ allophane weight), and 2.9, 2.3, and $3.1 \mathrm{wt} \%$ for the andosols with 5.9, 10.2, and 11.8 allophane weight $\%$, respectively (organic carbon was not measured for the 2.5 allophane weight $\%$ ).

Likewise, andosols show higher sorption capacity for a range of pesticides, such as atrazine, parathion, and cadusafos compared to other soils (Prado et al. 2014; Olvera-Velona et al. 2008; Müller et al. 2003). And, due to its adsorption capacity, allophane clay has been studied for use in water purification for benzene derivatives (Nishikiori et al. 2009), fluoride (Kaufhold et al. 2010), and boron (Reinert et al. 2011). 

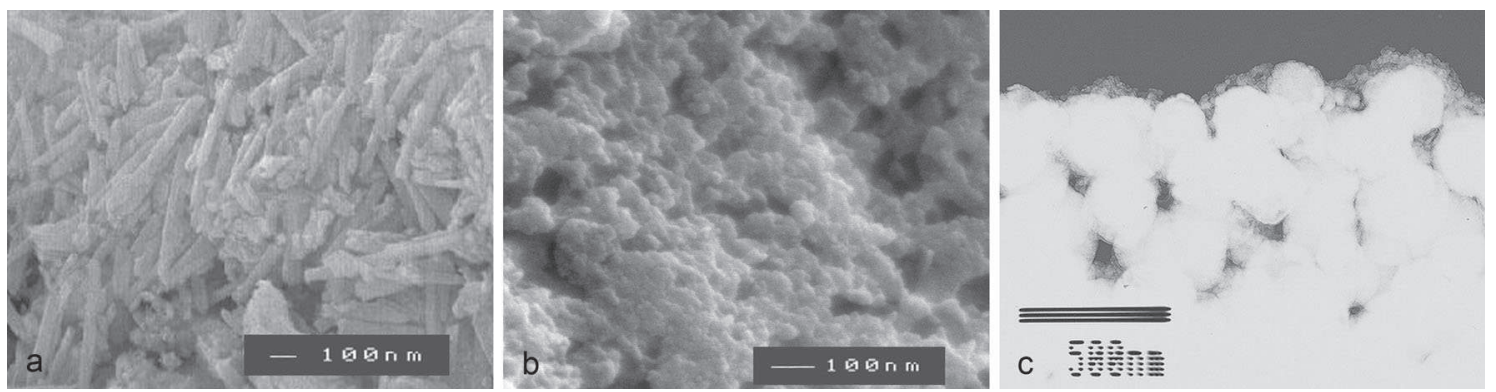

Fig. 1 Scanning electronic micrographs showing the structure of phyllosilicate clay (a) and allophane clay (b). Panel $\mathbf{c}$ shows the transmission electron micrographs of allophane clay

The structural properties of the mineral matrix with which pollutants are associated may influence pollutant bioavailability and retention in soils (Peters et al. 2007; Chung and Alexander 2002; Liu et al. 2009; Rana et al. 2009). Allophane is short-range order clay, whose porous structure and physical properties strongly differ from those of the crystalline clays as halloysite found in nitisols.

It is likely that the propensity of andosols for pollutant retention is related to the allophane microstructure and nanopore features. Data show that physical protection and adsorption of persistent pesticide are both higher in nanosized structures (Pignatello 1998; Calabi-Floody et al. 2012; Baldock and Skjemstad 2000). The combination of pore size and network tortuosity may play a key role in controlling pesticide inaccessibility to microorganisms and water. The decrease in bioavailability has often been explained by slow diffusion in small pores and can be physically explained as the result of entrapment of molecules (Arias-Estévez et al. 2008; Puglisi et al. 2007; Reid et al. 2000). It is necessary to explore the physical processes that explain these differences.

\section{Influence of allophane content on soil pore properties}

The data show that the pore volume $V p$ and the specific surface area $S$ were well correlated to the allophane contents (Fig. 3a, b). We found that $S\left(\mathrm{~m}^{2} \cdot \mathrm{g}^{-1}\right)=43.39+4.99$ allophane $(\%)$ $\left(P<0.0001\right.$ and $\left.r^{2}=0.87\right)$ and $V p\left(\mathrm{~cm}^{3} \cdot \mathrm{g}^{-1}\right)=0.58+0.059$ allophane $(\%)\left(P<0.0001\right.$ and $\left.r^{2}=0.79\right)$. The specific surface area could be as high as $200 \mathrm{~m}^{2} \cdot \mathrm{g}^{-1}$ and $V p$ close to $2 \mathrm{~cm}^{3} \cdot \mathrm{g}^{-1}$.

Large specific surface area is generally the signature of an important mesoporosity contribution (Gregg and Sing 1982). The literature (Adachi and Karube 1999; Wada 1985; Woignier et al. 2008) describes the allophane aggregates structure as fractal in the range of a few nanometer up to almost $100 \mathrm{~nm}$. This new study confirms that the fractal dimension is close to $2.6 \pm 0.1$ and the particles size ( $a$ ) extracted from the scattering spectra (SAXS) is constant (in the range 4-5 nm). The $D f$ constant means that the aggregation mechanism is quite the same, whatever the allophane concentration. The measured $D f$ is rather close to the fractal dimension (2.2) corresponding to the "Reaction limited cluster aggregation"
(Kolb et al. 1983) and the higher measured value (2.6 compared to 2.2) is likely the result of a restructuring with time (Jullien and Botet 1987).

We show that the size of the fractal aggregate $(L)$ increases with the allophane concentration (Fig. $3 \mathrm{c}, L(\mathrm{~nm})=6.65+1.95$ allophane (\%), $P<0.0001$ and $r^{2}=0.89$ ). When particles stick together to form clusters, they also create voids, i.e., pores, inside the clusters. These clusters stick together to form larger porous clusters with larger pores and so on, up to $L$ the maximum size of the fractal aggregates. Another important feature of fractal aggregates is their internal porosity (mesoporous volume Vmeso). Figure 3d shows a strong increase in the mesoporous volume Vmeso with the allophane Vmeso $=0.0008+$ 0.0197 allophane $(\%)\left(P<0.0001\right.$ and $\left.r^{2}=0.8018\right)$.

This kind of aggregation process leads to a porous structure with a high tortuosity $(t)$ which is another important property of fractal aggregates. $t$ can be derived from the fractal dimension $(D f)$ and the spreading dimension $(D l)$, the fractal dimension of the minimum path (Jullien and Botet 1987): $t=L^{(D f /}$ ${ }^{D l-1} \cdot a^{(D f f D l)-1}$.

For nanoporous microstructure close to allophane (silica gels), the spreading dimension $D l$ has been found experimentally to be close to 1.7 (Vacher et al. 1990) and thus the exponent $\lambda$ should be in the range 1.47 to 1.55 with $D f$ in the range 2.6. These $\lambda$ values are in a good agreement with the data found experimentally to be between 1.4 and 1.8 (Vacher et al. 1990; Courtens et al. 1987) and with the predictions of

Table 1 Transfer of chlordecone to water: the soil to water transfer coefficient (WTC) is the ratio of the pesticide concentration in lixiviates to the pesticide concentration in soil expressed in microgram per liter/ milligram per kilogram of dry soil. Differences between clay types were tested by ANOVA $(P=0.05)$ with seven replicates for andosol and eight for nitisol. The mean carbon content is 2.3 and $2.1 \mathrm{wt} \%$ for the andosol and nitisol, respectively

\begin{tabular}{llll}
\hline Soil and clay type & $\begin{array}{l}\text { Soil contamination } \\
\text { range (in mg CLD } \\
\mathrm{kg}^{-1} \text { dry soil) }\end{array}$ & MTC & \\
\cline { 3 - 4 } & & Mean & $\begin{array}{l}\text { Standard } \\
\text { deviation }\end{array}$ \\
\hline Andosol (allophane) & $3.4-6.7$ & 2.33 & 0.66 \\
Nitisol (halloysite) & $0.5-0.91$ & 4.68 & 1.07 \\
\hline
\end{tabular}




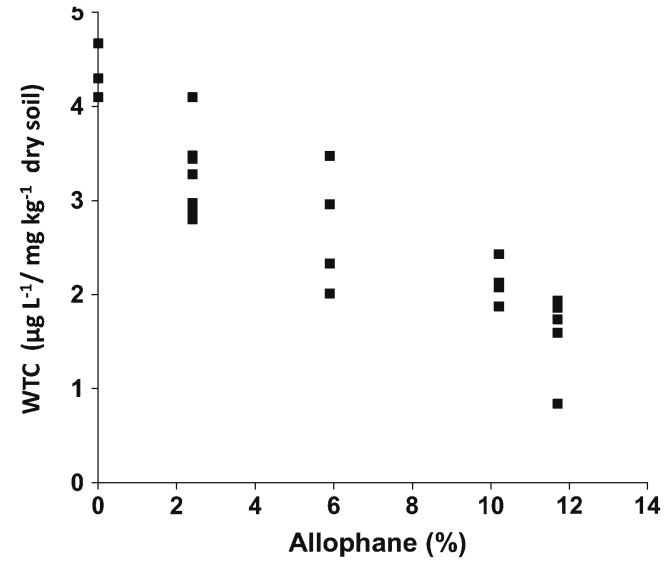

Fig. 2 Decrease of the soil to water transfer coefficient WTC with the allophane content

aggregation models (Herrmann and Stanley 1988; Meakin et al. 1984). We have no $D l$ value for the allophane aggregates, but we can assume that the $D l$ value is not very different from the $D l$ of nanoporous silica $D l=1.7$.

Figure $3 \mathrm{e}$ shows the increase of the aggregates tortuosity with the allophane content (calculated with $D l=1.7$ and the data found from the SAXS experiments: $D f=2.6, a=5 \mathrm{~nm}$ and the $L$ values from Fig. $3 \mathrm{c}$ ). Figure $3 \mathrm{e}$ shows the strong positive correlation of the allophane content with the aggregates tortuosity $(t): t=1.3628+0.082$ allophane $(\%)$ $\left(P<0.0001\right.$ and $\left.r^{2}=0.8593\right)$. The allophane aggregate microstructure resembles a labyrinth at the nanometer scale. This description suggests that the accessibility in the allophane microstructure decreases when the size of the labyrinth, the internal porosity, and tortuosity increase. This hypothesis is discussed thereafter.

\section{Influence of allophane features on the CLD retention}

A previous work (Woignier et al. 2012) has demonstrated the strong influence of the allophane content on the soil contamination. The new data confirm that the soil chlordecone content increases with the allophane content: $C L D=0.6223+$ 0.8951 allophane $(\%)\left(P<0.0001\right.$ and $\left.r^{2}=0.8257\right)$. It is reasonable to hypothesize that the ability for a soil to retain chemical species could be related to the soil structure and pore features (size of the cluster, mesopore volume, and tortuosity).

For pesticides, there is a need to establish the relationship between the retention mechanism and such physical parameters in allophanic soils. Figure 3f, g shows that the CLD concentration increases with the soil specific surface area $S$ : $C L D=0.13 S-4.36\left(P<0.0001\right.$ and $\left.r^{2}=0.80\right)$ and with the pore volume $C L D=9.56 \mathrm{Vp}-4.11\left(P<0.0001\right.$ and $\left.r^{2}=0.78\right)$.

Figure $3 \mathrm{~h}, \mathrm{i}, \mathrm{j}$ shows that the CLD soil concentration increases with the features of the clay fractal structure, i.e., the size of the fractal allophane aggregates $L(C L D=0.47 L-6.40$, $P<0.0001$ and $\left.r^{2}=0.71\right)$, the internal porosity of the aggregates Vmeso (CLD $=37.3$ Vmeso $-0.40, P<0.001$ and $\left.r^{2}=0.72\right)$, and the tortuosity $t(\mathrm{CLD}=4.6 t-2.36$, with $P<0.0001$ and $\left.r^{2}=0.61\right)$. This confirms the effect of the allophane microstructure on the pesticide trapping.

\section{Trapping mechanism in allophane microstructure}

The observed characteristics of allophane, high specific surface area and pore volume, and fractal features correspond to a highly tortuous microstructure and small mesopores. The fractal structure of allophane aggregates is typically in the range 5-100 $\mathrm{nm}$ and we may hypothesize that the accessibility inside the aggregates is reduced. Indeed, for example, the trapping inside allophane aggregates is sought to contribute to the protective effect of allophane on biodegradation of soil organic matter, the later becoming inaccessible to microorganisms and enzymes (Boudot 1992; Mayer 1994; Mayer et al. 2004; McCarthy et al. 2008; Zimmerman et al. 2004; Dahlgren et al. 2004).

Data show that the soil to water transfer coefficient (WTC) decreases with $L$, Vmeso, and $t$, respectively: WTC $=-0.0966 L+4.5798$ (with $P<0.0001$ and $r^{2}=0.75$ ), WTC $=-1.3752 t+4.90$ (with $P<0.0001$ and $r^{2}=0.82$ ), and WTC $=-15.12$ Vmeso +4.65 (with $P<0.0001$ and $\left.r^{2}=0.65\right)($ Fig. $4 \mathrm{a}-\mathrm{c}$ ).

These results emphasize the role of the clay fractal features $(L, V m e s o$, and $t)$ in entrapment of pesticides. The retention mechanism is developed in the following.

To put forth the importance of the allophanic microstructure, we fractionated an andosol (allophane) and a nitisol (halloysite) and analyzed the CLD content in the three size classes obtained: $>200 \mu \mathrm{m}$ (class a), 50 to $200 \mu \mathrm{m}$ (class b), and $<50 \mu \mathrm{m}$ (class c).

Table 2 shows the CLD concentration in milligram CLD per kilogram DS (dry soil) for the different soils samples. For halloysite soil samples, the CLD concentrations are close, between 0.66 and $0.99 \mathrm{mg} \mathrm{kg}^{-1}$ dry soil, for $\mathrm{a}, \mathrm{b}$, and $\mathrm{c}$ fractions. However, in the case of the allophanic soils samples, the CLD concentration strongly increases for the class c, CLD concentration being 8.8 -fold higher than the a fraction, these differences being highly significant $(P=0.007)$. This higher CLD content in the class is due to its richness in allophane aggregates (Filimonova et al. 2016). We observe that the CLD relative to $\mathrm{C} \%$ is systematically higher in andosol than in nitisols which comforts the assumption that the CLD retention cannot be explained only by the OC content.

\section{Pesticide availability and allophane microstructure}

The fate and behavior of organic pollutants in soils is governed by many different factors including soils characteristics and chemicals properties. The behavior of organic pesticides in soils has been reviewed by several excellent papers 
Fig. 3 Increase of the specific surface area $S$ (a), the total pore volume $V p(\mathbf{b})$, the size of the fractal aggregate $L(\mathbf{c})$, the mesopore volume Vmeso (d), and the tortuosity $t$ (e), with allophane content. And, increase of soil contamination with specific surface area $S(\mathbf{f})$, total pore volume $V p(\mathbf{g})$, the size of the fractal allophane aggregates $L(\mathbf{h})$, the mesopore volume Vmeso (i), and the tortuosity $t$ (j)
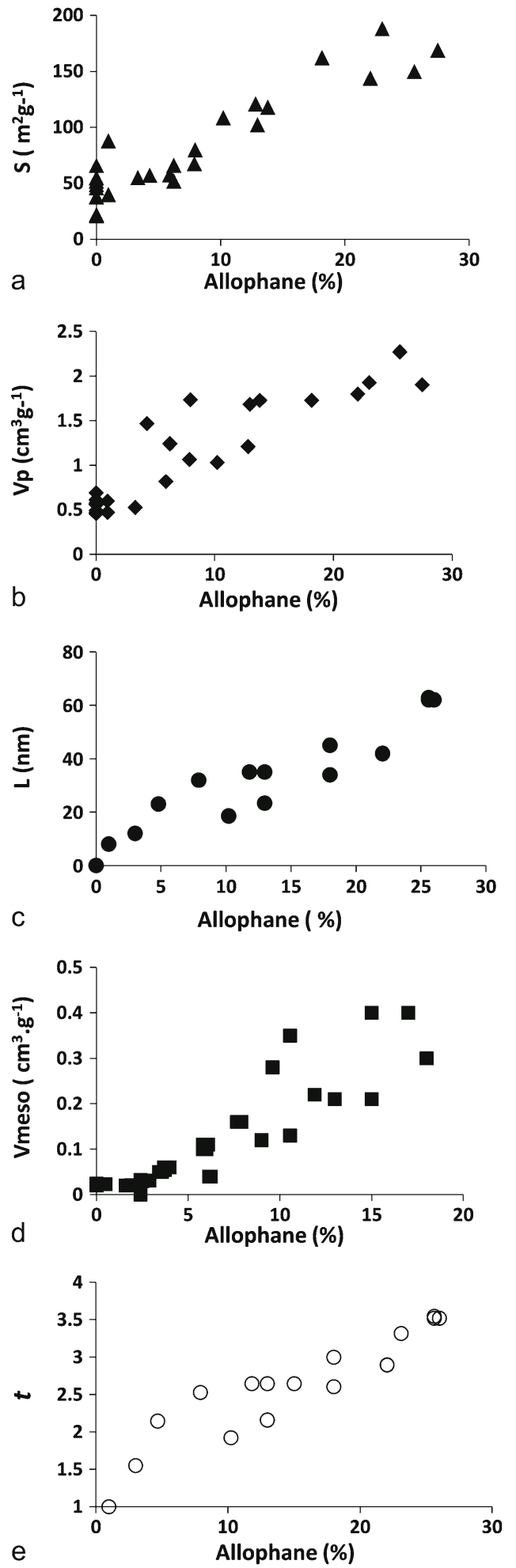
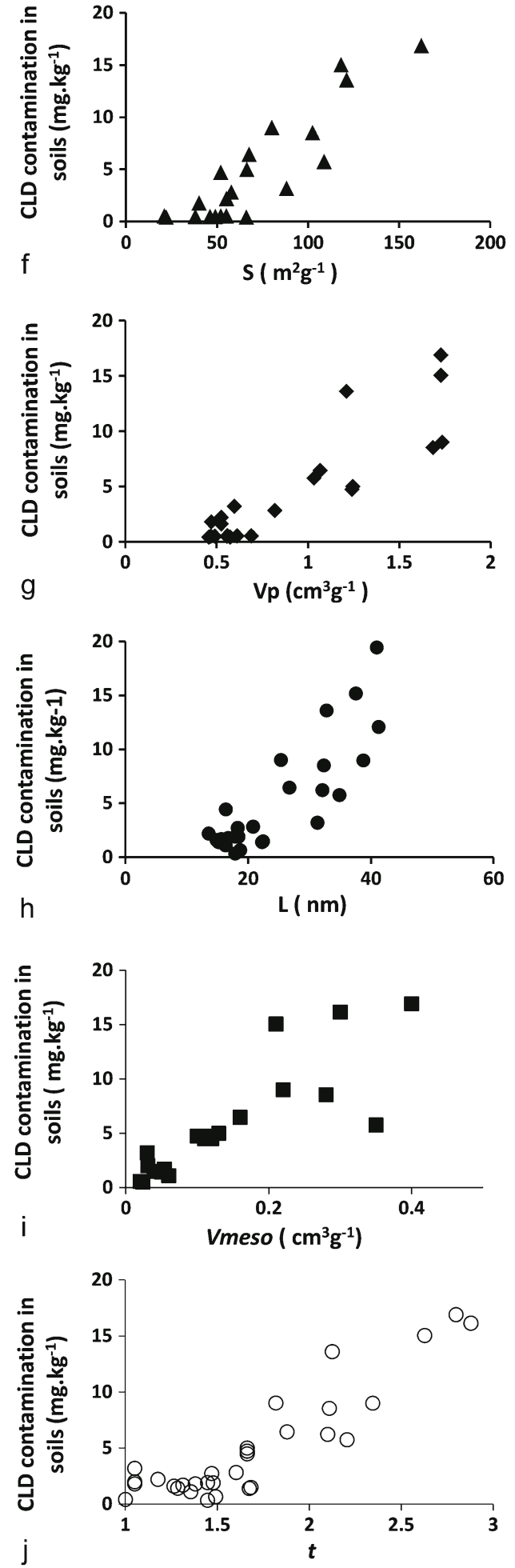

(Pignatello 1998; Pan et al. 2008; Cornelissen et al. 2005; Weber et al. 1999). It has been well documented that soil organic matter controls the behavior of pesticides, such as sorption, mobility, extractability, solubility, and bioavailability (Pan et al. 2008; Chiou et al. 1979). Adsorption-desorption behavior is one of the key processes affecting the bioavailability and the fate of agrochemicals. It is commonly accepted that sorbed chemicals are less accessible to microorganisms and that adsorption limits their transport (AriasEstévez et al. 2008). Adsorption-desorption hysteresis has been explained as the result of non-attainment of equilibrium (Huang and Weber 1997; Barriuso et al. 2004) and irreversible 

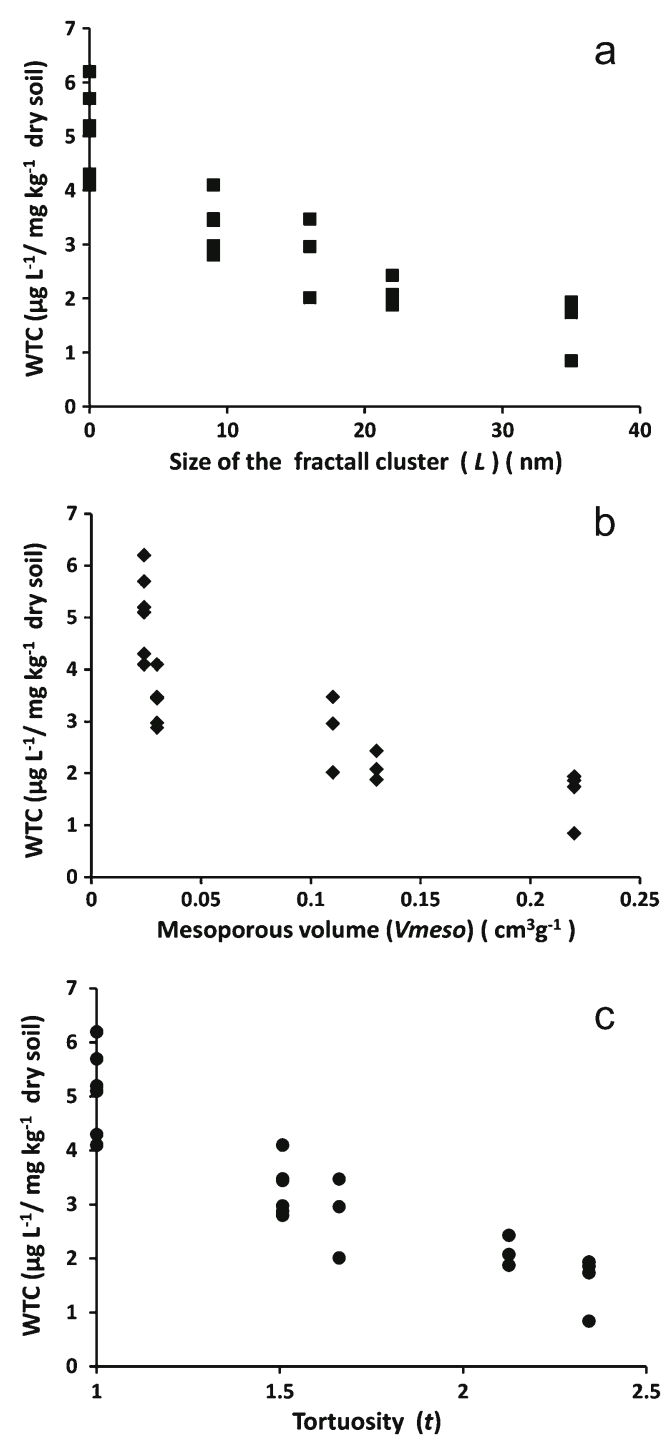

Fig. 4 Decrease of the soil to water transfer coefficient WTC with the size of the fractal allophane aggregates $L(\mathbf{a})$, the mesopore volume Vmeso (b), and the tortuosity $t$ (c)

binding to soil constituents such as organic matrices or inorganic structures (Huang et al. 2013).

Kleber et al. (2015) identify several factors that would facilitate binding of organic molecules in soils like the presence of reactive mineral phases with large specific surface areas.

Table 2 CLD concentration in the different size class a, b, and c for andosol and nitisols. Values are means of three replicates \pm standard error of the mean. Differences between fractions were tested by ANOVA. Different letters in the same row indicate significant differences (Tukey
Very reactive with respect to organic molecules sorption are weathering products such as the variably charged and usually nanometer-sized Fe oxides and short-range ordered Alsilicates like allophane. Kleber et al. (2005) explain that hydroxyl-bearing charges such as Fe hydroxides and poorly crystalline aluminosilicate protect the organic compounds by ligand exchange between mineral surface hydroxyls and negatively charged organic groups. Particle size controls the specific surface area and thus the amount of reactive surface groups per unit mass of mineral. Due to their small size and high specific surface area, nanoparticles are highly reactive with contaminants (Kleber et al. 2015). Last but not least, the soil porous features can limit the transport of chemicals compounds in the soil pore system and control exchanges with microorganisms. For example, the sequestration of organic matter within mineral mesopores has been hypothesized to protect organic matter from enzymatic degradation (Mayer 1994; Mayer et al. 2004; McCarthy et al. 2008; Zimmerman et al. 2004; Boudot 1992).

To explain the high pollutant content in allophanic soils, we can invoke the mesopore protection mechanism already proposed for organic matter. In addition to the mesopore protection mechanism, we point out the role of the fractal and tortuous porous microstructure. Organo-mineral complexes like allophane form small aggregates with pores in the mesopore scale $(2-50 \mathrm{~nm})$ and with high organic matter loadings: 75 to $90 \%$ of the soil organic matter found in the pores is in the 101000-nm size range (McCarthy et al. 2008). Such aggregate pore widths are far below the cutoff for accessibility by bacteria, which is considered to be $2 \mu \mathrm{m}$. Furthermore, enzymes can penetrate micropores and small mesopores but with difficulty, Zimmerman et al. (2004) showed that the enzyme activity was 3-40 times lower in mesoporous silica or alumina than that observed for nonporous minerals. The fractal aggregates in allophane clay likely sign tortuous diffusion pathways. In a previous work (Woignier et al. 2006), numerical simulations on porous structures have shown that permeability in allophane soils is strongly affected by the allophane content. The permeability at the scale of allophane aggregate has been calculated to be low $\left(40 \mathrm{~nm}^{2}\right)$ in these tortuous pore networks. These results are close to those measured in silica gels ( 10-20 $\mathrm{nm}^{2}$ ) (Reynes et al. 2001; Scherer 1992; Anez

test, $P=0.05$ ). The carbon contents (weight $\%$ ) are $0.99,1.77$, and 7.01 for the fractions a, b, and c, respectively (andosol), and 1.12, 1.76, and 2.34 for the fractions $\mathrm{a}, \mathrm{b}$, and c, respectively (nitisol)

\begin{tabular}{|c|c|c|c|c|c|c|c|}
\hline \multirow[b]{2}{*}{ Soil type } & \multicolumn{6}{|c|}{ CLD content (in mg CLD kg ${ }^{-1}$ dry soil) } & \multirow{2}{*}{$\begin{array}{l}\text { ANOVA } \\
\operatorname{Pr}>\text { F }\end{array}$} \\
\hline & Fraction a & & Fraction $\mathrm{b}$ & & Fraction c & & \\
\hline Andosol (allophanic clay) & $1.16 \pm 0.39$ & $\mathrm{a}$ & $2.14 \pm 0.26$ & $\mathrm{a}$ & $10.25 \pm 4.2$ & $\mathrm{~b}$ & 0.007 \\
\hline Nitisol (halloysite clay) & $0.66 \pm 0.11$ & $\mathrm{a}$ & $0.99 \pm 0.17$ & $\mathrm{~b}$ & $0.95 \pm 0.07$ & $a, b$ & 0.031 \\
\hline
\end{tabular}


et al. 2014). The value of the effective diffusion coefficient (for $\mathrm{Cs}^{+}$ion) in allophane was estimated to $10^{-16} \mathrm{~m}^{2} . \mathrm{s}^{-1}$, (Mon et al. 2005), 6 orders of magnitude smaller than the diffusion coefficient in aqueous solution. Thus, allophane aggregate structure might be highly porous but has a low permeability and diffusion coefficient; fluids and chemical species migrate with difficulty inside the fractal structure (Woignier et al. 2015). In addition, the fractal pore structure imposes a range of pore sizes including small as well as large ones. As an allophane aggregate increases in size, the tortuous diffusion pathway will become blocked by pore throats that prevent chemical or biological species passage. The fractal structure of the pore networks may, therefore, retard the enzyme diffusion to the adsorbed CLD and affect the degradation by microorganisms. The high CLD retention capacity is the result of different kinds of mechanism: (1) the high chemical affinity of chlordecone for organic matter would stabilize the pesticide in the mesoporosity. (2) Microorganisms supposed to be able to degrade the pesticide have a size higher than the allophane aggregates. (3) The low transport properties in allophane aggregate could explain the lesser chlordecone release in the environment, crops, and water resource. The synergy between organic matter content in allophane and tortuous microstructure prevents chlordecone from degradation when trapped inside the mesopore network. This trapping may reduce considerably the bioavailability of the pesticide and reinforce the poor pesticide degradation observed in this type of soil.

In Situ Chemical Reduction (ISCR) was tested to reduce the chlordecone soil content (Mouvet et al. 2016). ISCR treatment showed a poorer efficiency in andosol compared to nitisol and ferralsol. Due to the poor accessibility inside the allophane clusters, the ISCR efficiency may be limited by lower contaminant availability.

\section{Conclusion}

Allophanic clays are poorer secondary contaminant sources than phyllosilicates thus reducing the pesticide diffusion in the environment and food products. This study shows that there are clear correlations between clay microstructure and the soil pesticide content and retention:

1. The porous properties of clay aggregates strongly depends on the allophane content,

2. The soil contamination increases with the allophane content but also with the mesopore volume, the tortuosity, and the size of the fractal aggregate.

3. The pore structure of the allophane aggregates at nanoscale also favors the pesticide retention. It is suggested that chlordecone storage in allophanic soils could be the result of the low transport properties (permeability and diffusion) in the allophane aggregates.
The fractal and tortuous aggregates of nanoparticles play the role of nanolabyrinths.

The high pesticide content in allophanic soils is likely the result of a synergy between the high pesticide affinity with the organic matter and the poor accessibility to the pesticide trapped in the mesopore. Thus, these nanostructures both reduce the risk of a potential release of chlordecone and promote a protection of degradation by soil microorganisms of the organic matter.

Future research for chlordecone degrading microorganisms and other bioremediation tools to clean up polluted soils should take into account the reduced accessibility of chlordecone in the confining structure of the allophane nanolabyrinths.

Acknowledgements Funding was provided by the French Chlordecone National Plan ("JAFA" project), the French National Research Agency ("Chlordexco" project), and the French Ministry for Overseas development (MOM).

\section{References}

Adachi Y, Karube J (1999) Application of a scaling law to the analysis of allophane aggregates. Colloids Surf Physicochem Eng Asp 151(12):43-47

Addinsoft (1995-2013) XLSTAT version 2013.5.09. Addinsoft, Paris

Anez L, Calas-Etienne S, Primera J, Woignier T (2014) Gas and liquid permeability in nano composites gels: comparison of Knudsen and Klinkenberg correction factors. Microporous Mesoporous Mater 200:79-85. doi:10.1016/j.micromeso.2014.07.049

Arias-Estévez M, López-Periago E, Martínez-Carballo E, Simal-Gándara J, Mejuto J-C, García-Río L (2008) The mobility and degradation of pesticides in soils and the pollution of groundwater resources. Agric Ecosyst Environ 123(4):247-260. doi:10.1016/j.agee.2007.07.011

Baldock JA, Skjemstad JO (2000) Role of the soil matrix and minerals in protecting natural organic materials against biological attack. Org Geochem 31(7-8):697-710. doi:10.1016/S0146-6380(00)00049-8

Barois I, Dubroeucq D, Rojas P, Lavelle P (1998) Andosol-forming process linked with soil fauna under the perennial grass Mulhembergia macroura. Geoderma 86:241-260. doi:10.1016/s0016-7061(98) 00044-5 (In Eng)

Barrett EP, Joyner LG, Halenda PP (1951) The determination of pore volume and area distributions in porous substances. I. Computations from nitrogen isotherms. J am Chem Soc 73(1): 373-380

Barriuso E, Koskinen WC, Sadowsky MJ (2004) Solvent extraction characterization of bioavailability of atrazine residues in soils. J Agric Food Chem 52(21):6552-6556. doi:10.1021/jf0402451

Basile-Doelsch I, Amundson R, Stone WEE, Masiello CA, Bottero J-Y, Colin F, Masin F, Borschneck D, Meunier J-D (2005) Mineralogical control of organic carbon dynamics in a volcanic ash soil on La Reunion. Eur J Soil Sci 56:050912034650042

Bolan NS, Kunhikrishnan A, Choppala GK, Thangarajan R, Chung JW (2012) Stabilization of carbon in composts and biochars in relation to carbon sequestration and soil fertility. Sci Total Environ 424:264 270. doi:10.1016/j.scitotenv.2012.02.061

Boudot J-P (1992) Relative efficiency of complexed aluminum noncrystalline $\mathrm{Al}$ hydroxide, allophane and imogolite in retarding the biodegradation of citric acid. Geoderma 52(1-2):29-39. doi:10.1016/ 0016-7061(92)90073-G 
Bruckert S, Andreux F, Correa A, Ambouta K, Souchier B (1978) Fractionnement des agrégats applique à l'analyse des complexes organominéraux des sols. In: AISS (ed) Comptes-Rendus du llème Congrès International de Science du Sol. Edmonton, pp 88-89

Brunauer S, Emmett PH, Teller E (1938) Adsorption of gases in multimolecular layers. J am Chem Soc 60(2):309-319. doi:10.1021/ ja01269a023

Brunet D, Woignier T, Lesueur-Jannoyer M, Achard R, Rangon L, Barthès BG (2009) Determination of soil content in chlordecone (organochlorine pesticide) using near infrared reflectance spectroscopy (NIRS). Environ Pollut 157(11):3120-3125. doi:10.1016/j. envpol.2009.05.026

Cabidoche YM, Lesueur-Jannoyer M (2012) Contamination of harvested organs in root crops grown on chlordecone-polluted soils. Pedosphere 22(4):562-571. doi:10.1016/s1002-0160(12)60041-1

Cabidoche YM, Achard R, Cattan P, Clermont-Dauphin C, Massat F, Sansoulet J (2009) Long-term pollution by chlordecone of tropical volcanic soils in the French West Indies: a simple leaching model accounts for current residue. Environ Pollut 157(5):1697-1705. doi: 10.1016/j.envpol.2008.12.015

Calabi-Floody M, Bendall JS, Jara AA, Welland ME, Theng BKG, Rumpel C, Mora ML (2011) Nanoclays from an andisol: extraction, properties and carbon stabilization. Geoderma 161(3-4):159-167. doi:10.1016/j.geoderma.2010.12.013

Calabi-Floody M, Velásquez G, Gianfreda L, Saggar S, Bolan N, Rumpel C, Mora ML (2012) Improving bioavailability of phosphorous from cattle dung by using phosphatase immobilized on natural clay and nanoclay. Chemosphere 89(6):648-655. doi:10.1016/j. chemosphere.2012.05.107

Chevallier T, Woignier T, Toucet J, Blanchart E, Dieudonné P (2008) Fractal structure in natural gels: effect on carbon sequestration in volcanic soils. J Sol-Gel Sci Technol 48(1):231-238. doi:10.1007/ s10971-008-1795-Z

Chiou CT, Peters LJ, Freed VH (1979) A physical concept of soil-water equilibria for nonionic organic compounds. Science 206(4420): 831-832. doi:10.1126/science.206.4420.831

Chung N, Alexander M (2002) Effect of soil properties on bioavailability and extractability of phenanthrene and atrazine sequestered in soil. Chemosphere 48(1):109-115. doi:10.1016/s0045-6535(02)00045-0

Clark CJ, McBride MB (1984) Cation and anion retention by natural and synthetic allophane and imogolite. Clay Clay Miner 32(4):291-299

Clostre F, Lesueur-Jannoyer M, Achard R, Letourmy P, Cabidoche Y-M, Cattan P (2014a) Decision support tool for soil sampling of heterogeneous pesticide (chlordecone) pollution. Environ Sci Pollut res 21(3):1980-1992. doi:10.1007/s11356-013-2095-x (In English)

Clostre F, Woignier T, Rangon L, Fernandes P, Soler A, Lesueur-Jannoyer M (2014b) Field validation of chlordecone soil sequestration by organic matter addition. J Soils Sediments 14(1):23-33. doi:10. 1007/s11368-013-0790-3

Clostre F, Cattan P, Gaude J-M, Carles C, Letourmy P, Lesueur-Jannoyer M (2015a) Comparative fate of an organochlorine, chlordecone, and a related compound, chlordecone-5b-hydro, in soils and plants. Sci Total Environ 532:292-300. doi:10.1016/j.scitotenv.2015.06.026

Clostre F, Letourmy P, Lesueur-Jannoyer M (2015b) Organochlorine (chlordecone) uptake by root vegetables. Chemosphere 118:96102. doi:10.1016/j.chemosphere.2014.06.076

Coat S, Monti D, Legendre P, Bouchon C, Massat F, Lepoint G (2011) Organochlorine pollution in tropical rivers (Guadeloupe): role of ecological factors in food web bioaccumulation. Environ Pollut 159(6):1692-1701. doi:10.1016/j.envpol.2011.02.036

Colmet-Daage F, Lagache P, Jd C, Gautheyrou J, Gautheyrou M, Md L (1965) Caractéristiques de quelques groupes de sols dérivés de roches volcaniques aux Antilles françaises (Characteristics of a few soil groups resulting from volcanic rocks in the French West Indies). Cah ORSTOMSer Pedol III 3(2):91-121 (In French)
Cornelissen G, Gustafsson Ö, Bucheli TD, Jonker MTO, Koelmans AA, van Noort PCM (2005) Extensive sorption of organic compounds to black carbon, coal, and kerogen in sediments and soils: mechanisms and consequences for distribution, bioaccumulation, and biodegradation. Environ Sci Technol 39(18):6881-6895. doi:10.1021/ es050191b

Courtens E, Pelous J, Phalippou J, Vacher R, Woignier T (1987) Brillouin-scattering measurements of phonon-fracton crossover in silica aerogels. Phys rev Lett 58(2):128-131

Dahlgren RA, Saigusa M, Ugolini FC (2004) The nature, properties and management of volcanic soils. In: Advances in agronomy, vol Volume 82. Academic Press, pp 113-182. doi: 10.1016/S00652113(03)82003-5

Dallaire R, Muckle G, Rouget F, Kadhel P, Bataille H, Guldner L, Seurin S, Chajès V, Monfort C, Boucher O, Pierre Thomé J, Jacobson SW, Multigner L, Cordier S (2012) Cognitive, visual, and motor development of 7-month-old Guadeloupean infants exposed to chlordecone. Environ Res 118:79-85. doi:10.1016/j.envres.2012.07.006

Della Rossa P, Jannoyer M, Mottes C, Plet J, Bazizi A, Arnaud L, Jestin A, Woignier T, Gaude J-M, Cattan P (2017) Linking current river pollution to historical pesticide use: insights for territorial management? Sci Total Environ 574:1232-1242. doi:10.1016/j.scitotenv. 2016.07.065

Denaix L, Lamy I, Bottero JY (1999) Structure and affinity towards $\mathrm{Cd} 2+, \mathrm{Cu} 2+, \mathrm{Pb} 2+$ of synthetic colloidal amorphous aluminosilicates and their precursors. Colloids Surf Physicochem Eng Aspects 158(3):315-325. doi:10.1016/S0927-7757(99)00096-5

Dolfing J, Novak I, Archelas A, Macarie H (2012) Gibbs free energy of formation of chlordecone and potential degradation products: implications for remediation strategies and environmental fate. Environ Sci Technol 46(15):8131-8139. doi:10.1021/es301165p

Dorel M, Roger-Estrade J, Manichon H, Delvaux B (2000) Porosity and soil water properties of Caribbean volcanic ash soils. Soil Use Manage 16(2):133-140

Dubroeucq D, Geissert D, Quantin P (1998) Weathering and soil forming processes under semi-arid conditions in two Mexican volcanic ash soils. Geoderma 86:99-122. doi:10.1016/s0016-7061(98)00033-0

Dubuisson C, Héraud F, Leblanc J-C, Gallotti S, Flamand C, Blateau A, Quenel P, Volatier J-L (2007) Impact of subsistence production on the management options to reduce the food exposure of the Martinican population to chlordecone. Regul Toxicol Pharmacol 49(1):5-16. doi:10.1016/j.yrtph.2007.04.008

Epstein SS (1978) Kepone-hazard evaluation. Sci Total Environ 9(1):162. doi:10.1016/0048-9697(78)90002-5

Espinoza J, Fuentes E, Baez ME (2009) Sorption behavior of bensulfuron-methyl on andisols and ultisols volcanic ash-derived soils: contribution of humic fractions and mineral-organic complexes. Environ Pollut 157(12):3387-3395. doi:10.1016/j.envpol. 2009.06.028 (In eng)

Feller C (1979) Une méthode de fractionnement granulométrique de la matière organique des sols : application aux sols tropicaux, à textures grossières, très pauvres en humus (a method for granulometric fractionation of soil organic matter. Application to tropical soils with coarse textures and very low humus content.) Cahiers ORSTOM Série Pédologie 17(4):339-346 (In French)

Filimonova S, Kaufhold S, Wagner FE, Häusler W, Kögel-Knabner I (2016) The role of allophane nano-structure and Fe oxide speciation for hosting soil organic matter in an allophanic andosol. Geochim Cosmochim Acta 180:284-302. doi:10.1016/j.gca.2016.02.033

Fung CN, Zheng GJ, Connell DW, Zhang X, Wong HL, Giesy JP, Fang Z, Lam PKS (2005) Risks posed by trace organic contaminants in coastal sediments in the Pearl River Delta, China. Mar Pollut Bull 50(10):1036-1049. doi:10.1016/j.marpolbul.2005.02.040

Fushiwaki Y, Urano K (2001) Adsorption of pesticides and their biodegraded products on clay minerals and soils. J Health Sci 47(4):429-432. doi:10.1248/jhs.47.429 
Garrido-Ramirez EG, Sivaiah MV, Barrault J, Valange S, Theng BKG, UretaZañartu MS, Mora ML (2012) Catalytic wet peroxide oxidation of phenol over iron or copper oxide-supported allophane clay materials: influence of catalyst $\mathrm{SiO} 2 / \mathrm{Al} 2 \mathrm{O} 3$ ratio. Microporous Mesoporous Mater 162:189-198. doi:10.1016/j.micromeso.2012.06.038

Gimou M-M, Charrondiere UR, Leblanc J-C, Pouillot R (2008) Dietary exposure to pesticide residues in Yaoundé: the Cameroonian total diet study. Food Addit Contam Part a: Chem Anal Control Expo Risk Assess 25(4):458-471

Gregg S, Sing KS (1982) Adsorption, surface area, and porosity, 2nd edn. Academic Press, New York

Gustafsson JP, Bhattacharya P, Bain DC, Fraser AR, McHardy WJ (1995) Podzolisation mechanisms and the synthesis of imogolite in northern Scandinavia. Geoderma 66(3-4):167-184

Herrmann HJ, Stanley HE (1988) The fractal dimension of the minimum path in two- and three-dimensional percolation. J Phys Math Gen 21(17):L829

Huang W, Weber WJ (1997) A distributed reactivity model for sorption by soils and sediments. 10. Relationships between desorption, hysteresis, and the chemical characteristics of organic domains. Environ Sci Technol 31(9):2562-2569. doi:10.1021/es960995e

Huang Y, Liu Z, He Y, Zeng F, Wang R (2013) Quantifying effects of primary parameters on adsorption-desorption of atrazine in soils. $\mathrm{J}$ Soils Sed 13(1):82-93. doi:10.1007/s11368-012-0572-3

Jondreville C, Lavigne A, Jurjanz S, Dalibard C, Liabeuf J-M, Clostre F, Lesueur-Jannoyer M (2014) Contamination of free-range ducks by chlordecone in Martinique (French West Indies): a field study. Sci Total Environ 493:336-341. doi:10.1016/j.scitotenv.2014.05.083

Jullien R, Botet R (1987) Aggregation and fractal aggregates. World Scientific, Singapore

Kaufhold S, Dohrmann R, Abidin Z, Henmi T, Matsue N, Eichinger L, Kaufhold A, Jahn R (2010) Allophane compared with other sorbent minerals for the removal of fluoride from water with particular focus on a mineable Ecuadorian allophane. Appl Clay Sci 50(1):25-33

Kleber M, Mikutta R, Torn MS, Jahn R (2005) Poorly crystalline mineral phases protect organic matter in acid subsoil horizons. Eur J Soil Sci 56(6):717-725. doi:10.1111/j.1365-2389.2005.00706.x

Kleber M, Eusterhues K, Keiluweit M, Mikutta C, Mikutta R, Nico PS (2015) Chapter One-Mineral-organic associations: formation, properties, and relevance in soil environments. In: Donald LS (ed) Advances in agronomy, vol 130. Academic Press, pp 1-140. doi: 10. 1016/bs.agron.2014.10.005

Kolb M, Botet R, Jullien R (1983) Scaling of kinetically growing clusters. Phys rev Lett 51(13):1123-1126

Lesueur JM, Cattan P, Woignier T, Clostre F (eds) (2016) Crisis management of chronic pollution: contaminated soil and human health. Urbanization, industrialization and the environment series, vol 2. CRC Press, Boca Raton États-Unis (In eng)

Levard C, Doelsch E, Basile-Doelsch I, Abidin Z, Miche H, Masion A, Rose J, Borschneck D, Bottero JY (2012) Structure and distribution of allophanes, imogolite and proto-imogolite in volcanic soils. Geoderma 183-184:100-108. doi:10.1016/j.geoderma.2012.03.015

Lindner GG, Nakazawa H, Hayashi S (1998) Hollow nanospheres, allophanes 'all-organic' synthesis and characterization. Microporous Mesoporous Mater 21(4-6):381-386. doi:10.1016/S13871811(98)00002-X

Liu C, Li H, Teppen BJ, Johnston CT, Boyd SA (2009) Mechanisms associated with the high adsorption of dibenzo-p-dioxin from water by smectite clays. Environ Sci Technol 43(8):2777-2783. doi:10. $1021 / \mathrm{es} 802381 \mathrm{z}$

Maeda H, Hashimoto Y, Ishida EH (2009) Solidification mechanism of allophane by hydrothermal reaction. Appl Clay Sci 44(1-2):71-74. doi:10.1016/j.clay.2009.01.013

Marlière C, Despetis F, Etienne P, Woignier T, Dieudonné P, Phalippou J (2001) Very large-scale structures in sintered silica aerogels as evidenced by atomic force microscopy and ultra-small angle X-ray scattering experiments. J non-Cryst Solids 285(1-3):148-153. doi: 10.1016/S0022-3093(01)00446-X

Mayer LM (1994) Surface area control of organic carbon accumulation in continental shelf sediments. Geochim Cosmochim Acta 58(4): 1271-1284. doi:10.1016/0016-7037(94)90381-6

Mayer LM, Schick LL, Hardy KR, Wagai R, McCarthy J (2004) Organic matter in small mesopores in sediments and soils. Geochim Cosmochim Acta 68(19):3863-3872. doi:10.1016/j.gca.2004.03.019

McCarthy JF, Ilavsky J, Jastrow JD, Mayer LM, Perfect E, Zhuang J (2008) Protection of organic carbon in soil microaggregates via restructuring of aggregate porosity and filling of pores with accumulating organic matter. Geochim Cosmochim Acta 72(19):47254744. doi:10.1016/j.gca.2008.06.015

Meakin P, Majid I, Havlin S, Stanley HE (1984) Topological properties of diffusion limited aggregation and cluster-cluster aggregation. J Phys a Math gen 17(18):L975

Mizota C, Van Reewijk LP (1989) Clay mineralogy and chemistry of soils formed in volcanic material in diverse climatic regions. Soil Monograph $\mathrm{n}^{\circ} 2$. International Soil Reference and Information Center, Wageningen

Mon J, Deng Y, Flury M, Harsh JB (2005) Cesium incorporation and diffusion in cancrinite, sodalite, zeolite, and allophane. Microporous Mesoporous Mater 86(1-3):277-286. doi:10.1016/j.micromeso. 2005.07.030

Mouvet C, Dictor M-C, Bristeau S, Breeze D, Mercier A (2016) Remediation by chemical reduction in laboratory mesocosms of three chlordecone-contaminated tropical soils. Environ Sci Pollut Res 1-13. doi: 10.1007/s11356-016-7582-4

Müller K, Smith RE, James TK, Holland PT, Rahman A (2003) Spatial variability of atrazine dissipation in an allophanic soil. Pest Manag Sci 59(8):893-903. doi:10.1002/ps.693

Nishikiori H, Shindoh J, Takahashi N, Takagi T, Tanaka N, Fujii T (2009) Adsorption of benzene derivatives on allophane. Appl Clay Sci 43(2):160-163. doi:10.1016/j.clay.2008.07.024

Olvera-Velona A, Benoit P, Barriuso E, Ortiz-Hernandez L (2008) Sorption and desorption of organophosphate pesticides, parathion and cadusafos, on tropical agricultural soils. Agron Sustain Dev 28(2):231-238. doi:10.1051/agro:2008009 (In English)

Onodera Y, Iwasaki T, Chatterjee A, Ebina T, Satoh T, Suzuki T, Mimura H (2001) Bactericidal allophanic materials prepared from allophane soil: I. Preparation and characterization of silver/phosphorus-silver loaded allophanic specimens. Appl Clay Sci 18(3-4):123-134. doi: 10.1016/S0169-1317(00)00038-7

Pan B, Ning P, Xing B (2008) Part IV—-sorption of hydrophobic organic contaminants. Environ Sci Pollut res 15(7):554-564. doi:10.1007/ s11356-008-0051-y (In English)

Peters R, Kelsey JW, White JC (2007) Differences in p,p'-DDE bioaccumulation from compost and soil by the plants Cucurbita pepo and Cucurbita maxima and the earthworms Eisenia fetida and Lumbricus terrestris. Environ Pollut 148(2):539-545. doi:10.1016/ j.envpol.2006.11.030

Pignatello JJ (1998) Soil organic matter as a nanoporous sorbent of organic pollutants. Adv Colloid Interf Sci 76-77:445-467. doi:10. 1016/S0001-8686(98)00055-4

Prado B, Duwig C, Hidalgo C, Müller K, Mora L, Raymundo E, Etchevers JD (2014) Transport, sorption and degradation of atrazine in two clay soils from Mexico: andosol and vertisol. Geoderma 232 234:628-639. doi:10.1016/j.geoderma.2014.06.011

Puglisi E, Cappa F, Fragoulis G, Trevisan M, Del Re AAM (2007) Bioavailability and degradation of phenanthrene in compost amended soils. Chemosphere 67(3):548-556. doi:10.1016/j. chemosphere.2006.09.058

Quantin P, Balesdent J, Bouleau A, Delaune M, Feller C (1991) Premiers stades d'altération de ponces volcaniques en climat tropical humide (montagne pelée, martinique). Geoderma 50(1-2):125-148. doi:10. 1016/0016-7061(91)90030-w 
Rana K, Boyd SA, Teppen BJ, Li H, Liu C, Johnston CT (2009) Probing the microscopic hydrophobicity of smectite surfaces. A vibrational spectroscopic study of dibenzo-p-dioxin sorption to smectite. Phys Chem Chem Phys 11(16):2976-2985. doi:10.1039/B822635K

Rebiscoul D (2004) Etude de la pérennité des gels d'alteration de verres nucléaires. University of Montpellier II, Montpellier (In French)

Reid BJ, Jones KC, Semple KT (2000) Bioavailability of persistent organic pollutants in soils and sediments - a perspective on mechanisms, consequences and assessment. Environ Pollut 108(1):103112. doi:10.1016/S0269-7491(99)00206-7

Reinert L, Ohashi F, Kehal M, Bantignies J-L, Goze-Bac C, Duclaux L (2011) Characterization and boron adsorption of hydrothermally synthesised allophanes. Appl Clay Sci 54(3-4):274-280. doi:10. 1016/j.clay.2011.10.002

Reynes J, Woignier T, Phalippou J (2001) Permeability measurement in composite aerogels: application to nuclear waste storage. J nonCryst Solids 285(1-3):323-327. doi:10.1016/S0022-3093(01) 00474-4

Rouquerol J, Avnir D, Everett DH, Fairbridge C, Haynes M, Pernicone N, Ramsay JDF, Sing KSW, Unger KK (1994) Guidelines for the characterization of porous solids. In: J. Rouquerol FR-RKSWS, Unger KK (eds) Studies in surface science and catalysis, vol 87. Elsevier, pp 1-9. doi: 10.1016/S0167-2991(08)63059-1

Scherer GW (1992) Bending of gel beams: method for characterizing elastic properties and permeability. J Non-Cryst Solids 142:18-35. doi:10.1016/S0022-3093(05)80003-1

Soler A, Lebrun M, Labrousse Y, Woignier T (2014) Solid-phase microextraction and gas chromatography-mass spectrometry for quantitative determination of chlordecone in water, plant and soil samples. Fruits 69(4):325-339. doi:10.1051/fruits/2014021

Stanley HE, Family F, Gould H (1985) Kinetics of aggregation and gelation. J Polym Sci: Polym Symp 73(1):19-37. doi:10.1002/polc. 5070730107

Teixeira J (1988) Small angle scattering by fractal systems. J Appl Crystallogr 21:781-785

U. S. Environmental Protection Agency (2012) Estimation Programs Interface Suite ${ }^{\mathrm{TM}}$ for Microsoft ${ }^{\circledR}$ Windows. v4.1 edn. Washington, DC

UNEP (2007) Report of the Persistent Organic Pollutants Review Committee on the work of its third meeting. Addendum. Risk management evaluation on chlordecone. Geneva
Vacher R, Courtens E, Coddens G, Heidemann A, Tsujimi Y, Pelous J, Foret M (1990) Crossovers in the density of states of fractal silica aerogels. Phys Rev Lett 65(8):1008-1011

Vlčková K, Hofman J (2012) A comparison of POPs bioaccumulation in Eisenia fetida in natural and artificial soils and the effects of aging. Environ Pollut 160:49-56. doi:10.1016/j.envpol.2011.08.049

Wada K (1985) The distinctive properties of andosol. Adv Soil Sci 2:173229

Weber WJ Jr, Huang W, LeBoeuf EJ (1999) Geosorbent organic matter and its relationship to the binding and sequestration of organic contaminants. Colloids Surf Physicochem Eng Aspects 151(1-2):167179. doi:10.1016/S0927-7757(98)00820-6

Wells N, Theng BKG (1985) Factors affecting the flow behavior of soil allophane suspensions under low shear rates. J Colloid Interface Sci 104(2):398-408. doi:10.1016/0021-9797(85)90048-7

Woignier T, Reynes J, Phalippou J, Dussossoy JL, Jacquet-Francillon N (1998) Sintered silica aerogel: a host matrix for long life nuclear wastes. J Non-Cryst Solids 225:353-357. doi:10.1016/S00223093(98)00052-0

Woignier T, Braudeau E, Doumenc H, Rangon L (2005) Supercritical drying applied to natural "gels": allophanic soils. J Sol-Gel Sci Technol 36(1):61-68. doi:10.1007/s10971-005-2659-4

Woignier T, Primera J, Hashmy A (2006) Application of the DLCA model to natural gels: the allophanic soils. J Sol-Gel Sci Technol 40(2-3):201-207. doi:10.1007/s10971-006-7593-6

Woignier T, Primera J, Duffours L, Dieudonné P, Raada A (2008) Preservation of the allophanic soils structure by supercritical drying. Microporous Mesoporous Mater 109(1-3):370-375. doi:10.1016/j. micromeso.2007.05.019

Woignier T, Clostre F, Macarie H, Jannoyer M (2012) Chlordecone retention in the fractal structure of volcanic clay. J Hazard Mater 241242:224-230. doi:10.1016/j.jhazmat.2012.09.034

Woignier T, Clostre F, Cattan P, Lesueur-Jannoyer M (2015) Pollution of soils and ecosystems by a permanent toxic organochlorine pesticide: chlordecone - numerical simulation of allophane nanoclay microstructure and calculation of its transport properties. AIMS Environ Sci 2(3):494-510. doi:10.3934/environsci.2015.3.494

Zimmerman AR, Goyne KW, Chorover J, Komarneni S, Brantley SL (2004) Mineral mesopore effects on nitrogenous organic matter adsorption. Org Geochem 35(3):355-375. doi:10.1016/j.orggeochem. 2003.10.009 